\title{
Optimization of Machining Parameters for Minimization of Roundness Error in Deep Hole Drilling using Minimum Quantity Lubricant
}

\author{
Anis Farhan Kamaruzaman ${ }^{1,}$, Azlan Mohd Zain ${ }^{1}$, Noordin Mohd. Yusof ${ }^{2}$, and Farhad \\ Nadjarian $^{2}$ \\ ${ }^{1}$ Soft Computing Research Group, Faculty of Computing, Universiti Teknologi Malaysia, 81310 \\ UTM, Skudai, Johor, Malaysia \\ ${ }^{2}$ Faculty of Mechanical Engineering, Universiti Teknologi Malaysia, 81310 UTM, Skudai, Johor, \\ Malaysia
}

\begin{abstract}
This paper presents an experimental investigation of deep hole drilling using CNC milling machine. This experiment investigates the effect of machining parameters which are spindle speed, feed rate and depth of hole using minimum quantity lubricant on the roundness error. The experiment was designed using two level full factorial with four center point. Finally, the machining parameters were optimized in obtaining the minimum value of roundness error. The minimum value of roundness error for deep hole drilling is 0.0266 at the spindle speed is $800 \mathrm{rpm}$, feed rate is $60 \mathrm{~mm} / \mathrm{min}$, depth of hole is $70 \mathrm{~mm}$ and minimum quantity lubricant is $30 \mathrm{ml} / \mathrm{hr}$.
\end{abstract}

\section{Introduction}

The demands in industrial nowadays need for the application of machining process to produce a particular product compared to the use of manpower in the past. Therefore, various types of machines have been introduced so far. Prior conventional machining was applied as turning [1, 2], milling [3, 4] drilling [5, 6], grinding [7] and so on. By its desire to meet the needs and demands of the present time, non-conventional machining or modern machining was introduced as abrasive water jet (AWJ) $[8,9]$, electrochemical machining $(\mathrm{ECM})[10,11]$, electric beam machining $(\mathrm{EBM})[12,13]$ and etc. Each machining process applied is based on the products to be produced. Thus, for the production of deep holes, a particular machining process is needed namely deep hole drilling.

The difference between drilling and deep hole drilling is based on the concept of deep hole drilling itself. Deep hole drilling is defined by its depth to diameter ratio (D: d) where the ratio is greater than 10: 1 . In other definition, deep hole machining means machining of holes deeper than ten times the diameter of the holes. Deep hole drilling can be applied to a wide range of materials from aluminium to the super-alloy.

However, in order to produce a high-quality product range of issues that may affect the quality of the product is noteworthy. Furthermore, deep hole drilling process is a new

\footnotetext{
*Corresponding author: anisfarhankmi@yahoo.com
} 
machining process was introduced and there is not much research being done to improve the quality of the resulting holes. Deep hole drilling process involves the production of a deep hole where any machining parameters and constraints during the machining process is carried out can affect the quality of the hole.

The importance of deep hole drilling can be seen in some areas such as in the area of aerospace [14], oil and gas [15], mold and die [16] and others where the quality of the hole resulting the effectiveness of the product. Therefore, it is necessary to study and run the experiments to identify the effect of machining parameters on hole quality.

For this purpose, the effect of different combinations of spindle speed, feed rate, depth of hole and MQL was examined. The optimum machining parameters were specified and the effect of cutting parameters on the roundness error was investigated.

\section{Experimental Setup}

The deep hole drilling experiments were carried out on a Maho Deckel Model MH500E CNC milling machine. The workpiece material used in the experiment was steel alloy (Fig. 1). The tools use was twisted drills (Fig. 2). There are four machining parameters involved in conducting this experiments which are spindle speed, feed rate, depth of holes and minimum quantity lubricant (MQL). The four machining parameters and constraints involved in this experiment are shown in Table 1 below.

Table 1. Machining parameters and constraints.

\begin{tabular}{|l|c|}
\hline Machining parameters & Constraints \\
\hline Spindle speed $(V)$ & $700-900 \mathrm{rpm}$ \\
\hline Feed rate $(f)$ & $50-70 \mathrm{~mm} / \mathrm{min}$ \\
\hline Depth of hole $(d)$ & $65-75 \mathrm{~mm}$ \\
\hline Minimum quantity lubricant $(l)$ & $20-40 \mathrm{l} / \mathrm{hr}$ \\
\hline
\end{tabular}

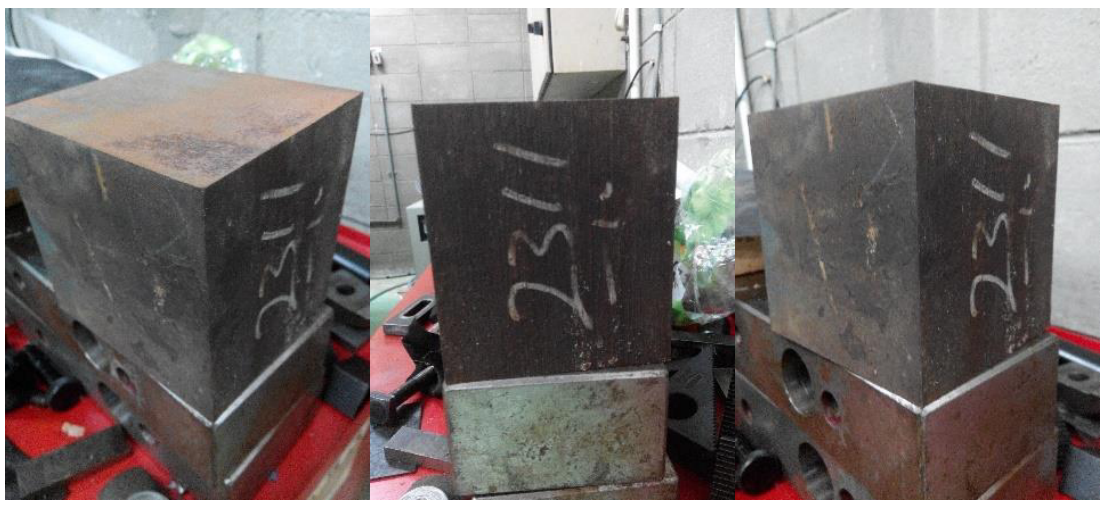

Fig. 1. Workpiece. 


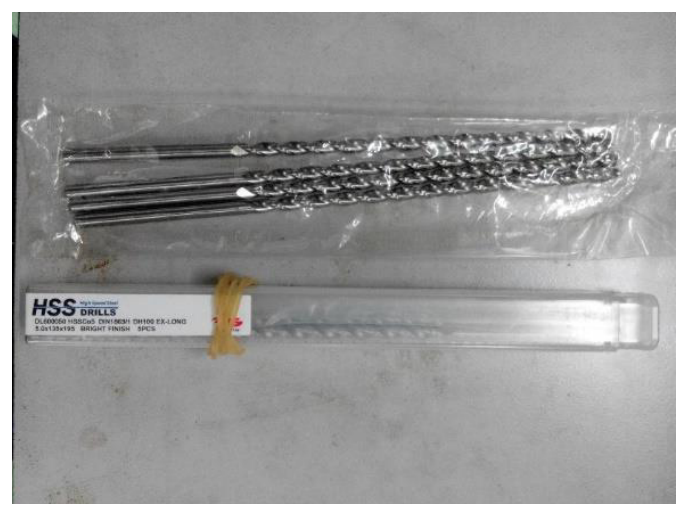

Fig. 2. Twist Drill.

The machine needs to be setup such as installing a workpiece, tool and MQL system. In the preliminary experiment, design of experiment (DOE) has been made using Minitab 17 software. The experiment was designed using two level full factorial with four center point. There are twenty tests conducted based on DOE. All experiments were performed based on the DOE. Therefore, this experiment involves twenty experiments to identify the effect of machining parameters on roundness error while identifying the optimum machining parameters to produce a minimum roundness error. The output which is roundness error was measured by a coordinate measuring machine (CMM).

\section{Results and discussion}

The variation of the roundness error of the drilled holes in relation to machining parameters involved was analyzed in this research. The result of experiments for roundness error is shown in Table 2 as shown below.

The result for optimization of machining parameters of deep hole drilling for roundness error is $0.0266 \mathrm{~mm}$. The optimal machining parameters are $800 \mathrm{rpm}$ for cutting speed $(V)$, $60 \mathrm{~mm} / \mathrm{min}$ for feed rate $(f), 70 \mathrm{~mm}$ for deep of hole $(d)$ and $30 \mathrm{l} / \mathrm{hr}$ for minimum quantity lubricant $(l)$. It was found that minimum roundness error obtained at hole 20.

The ANOVA has been used to obtain the relative effect of the different factors by the decomposition of variance. By using ANOVA, the relative effect of the machining parameters with respect to diameter error was investigated to determine the optimal combination of the machining parameters. The results of ANOVA for this experiment was generated by Design Expert 7. 
Table 2. The result of experiments for roundness error.

\begin{tabular}{|c|c|c|c|c|c|}
\hline & $\begin{array}{c}\text { Spindle } \\
\text { speed }(\boldsymbol{V})\end{array}$ & $\begin{array}{c}\text { Feed rate } \\
(\boldsymbol{f})\end{array}$ & $\begin{array}{c}\text { Depth of hole } \\
(\boldsymbol{d})\end{array}$ & $\begin{array}{c}\text { Minimum } \\
\text { quality } \\
\text { lubricant }(\boldsymbol{l})\end{array}$ & $\begin{array}{c}\text { Roundness } \\
\text { error }\end{array}$ \\
\hline Hole 1 & 700 & 50 & 65 & 20 & 0.0327 \\
\hline Hole 2 & 700 & 70 & 65 & 20 & 0.0400 \\
\hline Hole 3 & 700 & 50 & 75 & 20 & 0.0550 \\
\hline Hole 4 & 700 & 70 & 75 & 20 & 0.0563 \\
\hline Hole 5 & 800 & 60 & 70 & 30 & 0.0527 \\
\hline Hole 6 & 700 & 50 & 65 & 40 & 0.0565 \\
\hline Hole 7 & 700 & 70 & 65 & 40 & 0.0639 \\
\hline Hole 8 & 700 & 50 & 75 & 40 & 0.0545 \\
\hline Hole 9 & 700 & 70 & 75 & 40 & 0.0605 \\
\hline Hole 10 & 800 & 60 & 70 & 30 & 0.0678 \\
\hline Hole 11 & 900 & 50 & 65 & 20 & 0.0683 \\
\hline Hole 12 & 900 & 70 & 65 & 20 & 0.0668 \\
\hline Hole 13 & 900 & 50 & 75 & 20 & 0.0467 \\
\hline Hole 14 & 900 & 70 & 75 & 20 & 0.0625 \\
\hline Hole 15 & 800 & 60 & 70 & 30 & 0.0457 \\
\hline Hole 16 & 900 & 50 & 65 & 40 & 0.0340 \\
\hline Hole 17 & 900 & 70 & 65 & 40 & 0.0366 \\
\hline Hole 18 & 900 & 50 & 75 & 40 & 0.0502 \\
\hline Hole 19 & 900 & 70 & 75 & 40 & 0.0524 \\
\hline Hole 20 & 800 & 60 & 70 & 30 & 0.0266 \\
\hline
\end{tabular}

In Table 3, the results indicate that all the parameters are not significant for roundness error value as the $\alpha$ value used in ANOVA is 0.05 . If $p<0.05$, it shows that the observed different within four machining parameters are significant. However, all the machining parameters have $\mathrm{p}>0.05$ which refer to the insignificant. This situation could indicate that this effect was certainly masked by the action of uncontrolled factors. These results would lead us to believe that some machining parameters need for improving this process. 
Table 3. ANOVA for roundness error.

\begin{tabular}{|c|c|c|c|c|c|c|}
\hline \multicolumn{7}{|c|}{ ANOVA for selected factorial model } \\
\hline \multicolumn{7}{|c|}{ Analysis of variance table [Partial sum of squares - Type III] } \\
\hline Source & $\begin{array}{l}\text { Sum of } \\
\text { Squares }\end{array}$ & df & $\begin{array}{c}\text { Mean } \\
\text { Square }\end{array}$ & $\begin{array}{c}\mathbf{F} \\
\text { Value }\end{array}$ & $\begin{array}{c}\text { p-value } \\
\text { Prob }>\text { F }\end{array}$ & \\
\hline Model & 0.002047044 & 4 & 0.000511761 & 0.37576955 & 0.8221 & \multirow{5}{*}{$\begin{array}{c}\text { not } \\
\text { significan }\end{array}$} \\
\hline $\begin{array}{l}\text { A-Spindle } \\
\text { Speed }\end{array}$ & 0.000607178 & 1 & 0.000607178 & 0.445831272 & 0.5152 & \\
\hline $\begin{array}{l}\text { B-Feed } \\
\text { Rate }\end{array}$ & $2.90946 \mathrm{E}-05$ & 1 & $2.90946 \mathrm{E}-05$ & 0.021363237 & 0.8859 & \\
\hline $\begin{array}{l}\text { C-Depth of } \\
\text { Hole }\end{array}$ & $9.95027 \mathrm{E}-05$ & 1 & 9.95027E-05 & 0.07306162 & 0.7909 & \\
\hline D-MQL & 0.001311268 & 1 & 0.001311268 & 0.962822072 & 0.3431 & \\
\hline Curvature & $3.39506 \mathrm{E}-05$ & 1 & $3.39506 \mathrm{E}-05$ & 0.024928854 & 0.8768 & $\begin{array}{c}\text { not } \\
\text { significant }\end{array}$ \\
\hline Residual & 0.019066614 & 14 & 0.001361901 & & & \\
\hline Lack of Fit & 0.015154451 & 11 & 0.001377677 & 1.056457169 & 0.5485 & $\begin{array}{c}\text { not } \\
\text { significant }\end{array}$ \\
\hline Pure Error & 0.003912163 & 3 & 0.001304054 & & & \\
\hline Cor Total & 0.021147608 & 19 & & & & \\
\hline
\end{tabular}

\section{Conclusion}

The experiment was conducted under three machining parameters and minimum quantity lubricant have managed to find a minimum value of roundness error. The minimum value of roundness error is 0.0266 at the spindle speed is $800 \mathrm{rpm}$, feed rate is $60 \mathrm{~mm} / \mathrm{min}$, depth of hole is $70 \mathrm{~mm}$ and MQL is $30 \mathrm{ml} / \mathrm{hr}$. The validation for the results of the experiment was performed using ANOVA. However the results were exhibited by ANOVA showed that the machining parameters and MQL is not significant to the roundness error. Therefore, the enhancements to the experiment need to be done to produce a better result.

Special appreciation to reviewer(s) for useful advice and comments. The authors greatly acknowledge the Research Management Centre, UTM and Ministry of Higher Education Malaysia(MOHE) for financial support through the Fundamental Research Grant Scheme (FRGS) No.R.J130000.7828.4F721.

\section{References}

1. T. Liu, C.J. Kim, Science, 346, 6213 (2014)

2. A.R. Yildiz, Inform. Sciences, 220, 399 (2013)

3. A.M. Zain, , H. Haron, S. Sharif, Expert Syst. Appl., 37(2), 1755 (2010)

4. A.M. Zain, H. Haron, S. Sharif, Expert Syst. Appl., 37(6), 4650 (2010)

5. J. Prasanna, L. Karunamoorthy, M.V. Raman, S. Prashanth, D.R. Chordia, Measurement, 48, 346 (2014)

6. J.S. Nam, D.H. Kim, H. Chung, S.W. Lee, J. Clean. Prod., 102, 428 (2015)

7. B. Ping, Y.C. Fu, , Z.W. Zhang, Z.C. Zhao, Mater. Sci. Forum, 770, 263 (2014) 
8. A.M. Zain, H. Haron, S. Sharif, , Expert Syst. Appl., 38(7), 8316 (2011)

9. A.M. Zain, H. Haron, S. Sharif, Appl. Soft. Comput., 11(8), 5350 (2011)

10. B. Ghoshal, B. Bhattacharyya, Int. J. Mach. Tool. Manu., 64, 49 (2013)

11. F. Klocke, M. Zeis, S. Harst, A. Klink, D. Veselovac, M. Baumgartner, Procedia CIRP, 8, 265 (2013)

12. M. Cronskar, M. Backstrom, L.E. Rannar, Rapid Prototyping J., 19(5), 365 (2013)

13. H.K. Rafi, N.V. Karthik, H. Gong, T.L. Starr, B.E. Stucker, J. Mater. Eng. Perform, 22(12), 3872 (2013)

14. O. Yilmaz, A.T. Bozdana, M.A. Okka, Int. J. Adv. Manuf. Tech., 74(9-12), 1323 (2014)

15. S. Agarwal, T.X. Phuoc, Y. Soong, D. Martello, R.K. Gupta, Can. J. Chem. Eng., 91(10), 1641 (2013)

16. M.C. Cakir, O. Irfan, K. Cavdar, Robot Cim-Int. Manuf., 21(2), 175 (2005) 